12th LUMEN International Scientific Conference Rethinking Social Action. Core Values in Practice | RSACVP 2019 | 15-17 May 2019 | lasi-

Romania

\title{
The Symbol, the Sign and the Secret in the Ecstatic Language of the Zohar
}

\author{
Marius CUCU, Oana Elena LENȚA \\ https://doi.org/10.18662/lumproc.154
}

How to cite: Cucu, M., \& Lenţa, O.E. (2019). The Symbol, the Sign and the Secret in the Ecstatic Language of the Zohar. In C. Ignatescu (ed.), 12th LUMEN International Scientific Conference Rethinking Social Action. Core Values in Practice, 15-17 May 2019, Iasi - Romania (pp. 66-73). Iasi, Romania: LUMEN Proceedings. https://doi.org/10.18662/lumproc.154 


\title{
The Symbol, the Sign and the Secret in the Ecstatic Language of the Zohar
}

\author{
Marius CUCU ${ }^{1}$, Oana Elena LENȚA²*
}

Abstract

Humanity has always sought formulas of access to the timeless register of the transcendence, depending on the mode of perception and representation of it, and not least in the light of the cultural level and of the value system which the subject reported to. The text of the Zohar or the Book of Splendor fits in the tradition of mystical writings that try to assume not only a way of thinking relying on the immanent-transcendent polarity, but also on living the ecstasy of finding themselves on the boundary of the two dimensional paradigmatic frameworks. Such an individual experience can only be expressed and potentiated through the recourse to typologies of the mystical language including the fusion of the symbol, the sign and the secret. For the initiated one, considered the master, but also for the disciple, the mysteries of transcendence, of spirituality of the divine world cannot be accessed only through a comprehensive exercise of detaching the consciousness from the materiality. This implies not only the meditation, but also the adoption of a language that does not express the Spirit, but opens the way for the Spirit. Thus, it is considered that the call of the divinity is a mystery around which the soul of the individual may only linger in an ecstatic way and once it previously reached a maximum level of catharsis, purification and enlightenment.

Keywords: Kabbalah; Zohar; sign; symbol; secret; ecstasy; divine name; mystery; time; transience; initiated.

\section{Introduction}

The opening of the artist's consciousness toward benchmarks beyond appearance, beyond what appears naturally and immediately, is determined by the time of the meeting, namely, of the confrontation with the architecture of the symbolism. Thus, the act of interpretation itself involves standing in front of what needs to be interpreted. It is only through the success of the interpretative approach that one can achieve the leap

\footnotetext{
${ }^{1}$ PhD Lecturer, "Ştefan cel Mare” University, Suceava, România, mariuscucu35@yahoo.com

${ }^{2 *} \mathrm{PhD}$ Assistant, "Ştefan cel Mare" University, Suceava, România, oanalenta@yahoo.com 
across the border between semblance and primordial meaning, between immanent and transcendent, between physical expression and metaphysical meaning. The symbol, in its whole enigmatic and challenging occurrence, is often accompanied by the presence of the sign and the secret. Bringing together these three elements may give the actual measure of the meeting between the contemplative human spirit and the paradigm of a spiritual perimeter which is hidden and unemployed in the features and axioms of transience, of the spatio-temporal dimension of the mundane materiality. The exercise of the performer meets, therefore, this symbiosis between symbol, sign and secret and the effort of decoding such a fusion turns into an individual breakthrough for the hermeneut's consciousness. Thus, the fact of assuming such a mission causes an individual spiritual completion, an evolutionary transformation of personal capacities.

What are the conditions for such an ecstatic utterance and how do they relate to the conceptual dialectic between time and eternity? Is the text of Zohar the product of an exclusive perspective that proposes unilaterally the possibility of "uplifting" to a small initiated group or, conversely, provides an example of possible overcoming of limits in spiritual thought and ascension for the entire mankind? Can the ecstatic language be used by a small circle of "elected individuals" or may it be accessed by any consciousness that perseveres in the projection towards transcendence? Does it contain or not the symbol of a desirable conduct code? These are some issues that we intend to deal with in the present paper, asking to ourselves to what extent they are relevant for present-day that often mistakes religion for faith practice, the mystical experience for fanaticism, it confuses the fact that the memorization and the evocation of verses is not tantamount to the moral sense, etc.

\section{The Ecstatic Language of the Zohar}

On this reality of the interpretative experience seem to stake the authors of the text Sefer Ha-Zohar or the Book of Splendor, one of the pivotal components of the construction of the Kabbalab as representative work of meditation and Jewish mystical experience. The two authors, Rabbi Simeon ben Yobai and his son, Rabbi Eleazar, do not claim to be the authors, but the interpreters of some divine visions and indications that emerged from inner drives exacerbated from a mystical viewpoint. Faith and revelation seem to be the essential means that open the field to the ecstatic knowledge. But such an experience and knowledge cannot be simply presented like a cultural report or a simple pertinent analytical observation. It is about the ultimate 
elements, about assumptions that underlie the entire destiny of mankind and the genesis of the Universe. God, as the absolute Being and the man, as his creation that has an eschatological aim and meaning, his damnation and his salvation, the sin as destructive removal act in relation to the divine axis or the mechanisms of holiness are topics that cannot be exposed strictly rationally, by using a formal and equidistant language. On the contrary, the approach to such issues requires a full mystical experience of the exhibitor and the presentation of this experience and of the related information in an ecstatic language that joins, indeed, the symbol, the sign, and the secret. Mention is made that the writer is not one who presents the data received in such a language, but this data is received, offered and accepted in the form of an utterance that joins the force of suggestion and of calling the sign, the symbol and the secret. For the authors of the Zohar, this would be the method of expression of the Divinity, God speaks to us like this and the mission of the humans, as spirits chosen to live the religious faith, would be to assume such a communicative system of particular order. In other words, the divinity would address to the Adamic man by assigning such an information value code. The writers of the Zohar do not appear to be creators, but only witnesses to the word of the Lord, asking not just listening but, first and foremost, ecstatic involvement and assign the act of revelation only by agreeing with piousness and human spiritual raising.

The symbol appears as a landmark which relates to another level than the one originally brought into the exposed foreground, the symbol does not act as if it were an ultimate gnoseologic milestone. On the contrary, it acts as an intermediate knowledge factor, it indicates, suggests and leads onto an informational field located beyond it. In this context appears the phenomenon of symbols, of sending and opening onto a frame positioned in the extension of the symbol. It can be said therefore that the symbol can be seen as an expressive extension of such a hidden paradigm. In such cases, the observatory will go through two major experiences. It is about experiencing the confrontation with the mirage and the force of expression of the symbol and, then, about the intense feeling of the process of its decoding, followed by the leap toward the universe of what is symbolized. The observer's consciousness will be subjected to a comprehensive process of transformation, from the status of caller towards the level of an interpretation and projection in the sense of some unsuspected meanings. In the case of mystic symbolism, even more so, the impact of the meeting with the religious symbol and the ecstatic assumption of this one involves a profound transformation at the level of individual consciousness. The text of the Zohar claims that through each symbol pronounced and presented that enters the area of contact with the reader, to this latter is induced a new 
ecstatic state that leads to another step in the framework of his spiritual evolution. A symbol that the text of the Zohar offers would require a full assumption in the sense of the adoption without reserve of the meaning and of its transcendent opening. If the Divinity addresses to the man through symbols, then these latter should be lived fully and intensely in the mystical faith and it is only from this ecstatic experience that can begin the process of understanding of the supra-logical nature of the message delivered. The situation is similar to the understanding of a dream which cannot be obtained except in so far as the dreamer realizes a self-awareness at the level of the experience, of the feelings that were generated by that oniric experience. Before one asks what the meaning of the dream is, it is necessary to ask what he felt in that dream. The divine symbol evoked in the text of the Zohar should, likewise, be felt, lived in the fullness of its spiritual strength, in order to also elucidate a possible message, adaptable to the requirements of the discursive rationality. Of course, such adaptations reduce considerably the force of the mystic message, but they may be relevant from a religious perspective if they are developed after the symbolic revelation and its experiencing. It may be evoked here that a lot of the events recorded in the New Testament are of epiphanic-revelatory nature, and they seem to have been fully explored and later epistolary related to all mankind. In this respect the statement of the prophet Isaish according to which if you don't believe, you won't understand has acquired its persistence.

The sign involves, first, a projective type in relation to reality. Thus, it indicates a rollup of information meant to formalize it, to reduce it up to abstract data taken from the everyday environment [1]. The sign is an element that, unlike the symbol, does not open the way towards complex fields, of maximum extension, but it sends to specific targets, to exact points that are clearly delimited and circumscribed. The substantial difference between sign and symbol is, however, precisely the non implication of the observer or of the reader at the level of consciousness. Thus, while the symbol demands to be lived and assumed, generating an enormous emotional intensity, the sign only conveys the information clearly and technically without the involvement of feelings. The sign language is one that can be close to the tehnical language, to the one of an elaborated machine-like language, indicating separate structures, fixed elements, clearly differentiated and without a real interdependence in relation to other adjacent structures. Instead, the symbol, calling to the attention of the observer, aims at an overall perspective of the hidden connections, of interrelations that aim at the ontic totality as a network of information and experiences that exist in an overall entirety [2]. The sign in the text of the Zohar is present as an auxiliary element that supports the information, it 
refers to the limited but precise components required for the ritual religious act. The presence of the sign confers more technicality to a text which could entail risks of losses in a symbolic and mystical delirium.

The secret is one of the determinant factors in the process of human knowledge. Through the fact that it does not expose directly the information, the secret attracts thanks to an overpowering magnetism, strategies of analysis and sounding. When meeting a secret, the human knowledge faces a hurdle that may obstruct, initially, its systematic call and request. In front of a secret, the process of the cognitive understanding stops in order to reassess its full potential and possible limitation, the range of resources and the corresponding terms. It is barely through a resurrection at the level of its own structure and techniques of approach, that the beginning of an opening towards the profound and hidden meanings of a secret may be possible. From this perspective, the text of the Zohar evokes the issue of the divine secret, of the transcendent mystery that is posited as the supreme mystery of the almighty God. The image brought into question in order to ascertain the position of the divine mystery is the one of the clothes put on the structure of the human corporality. Thus, the noninitiated, the newbies, are those who only see these clothes in their colors and structural complexity. Those who acquire a more advanced state of knowledge might notice the body wearing these clothes and the ones who have been initiated would have the ability to see the soul, the spirit of what lies behind the body and its clothes. This view of the spirit symbolizes the sight of the divine mystery, the access to the primary secret. Once one has reached this level, the mystery does not appear like a general informative opening, it cannot be disclosed and exposed to the public. The mystery should be preserved as a mystery and the master who acquires access to it could be able to facilitate the opening towards it only to his disciple. But this achievement is made through mechanisms of mystical symbolization and encryption. The sacrament is passed to the disciple through allegorical language. The provision of such a mystical secret to the non-initiated public would equate to a reduction or even the cancellation of the spiritual potentiality of this secret, that is to the cancellation of its divine meaning. The initiates who are said to have access to the absolute secret are named the Supreme King's servants and their disciples should follow the law of sacred silence. Such a secret is constituted for the tradition of the Zohar the Name of God, secret that could be named by the High Priest in the Temple in Jerusalem once a year. Thus, its spiritual meaning and force were intensely protected and maintained in the area of a withdrawal from the area of analysis and determination of profane knowledge. Of course, the idea evoked in this context may entail, at first sight, shades of an exclusive 
positioning. The fact that the secrecy, the divine mystery is owned and preserved only by a narrow elitist group that denies the access of the majority to it, can be interpreted according to the idea that a collective religious selfishness would be present in this situation. In fact, assuming the preservation of such a secret is tantamount to taking a prophetic and taumaturgical role in relation to the profane collectivity. The initiated ones assume the act of mediation between the deity and the rest of humanity. The Zohar proposes the image of a personalized Deity who decides in relation to human presence that he has generated demiurgically. Therefore, it is not about the proposal of a cult that supports the existence of a universal soul in which the individual human consciousnesses should return symbiotically, as it happens in the case of the post-Vedic traditions [3]. On the contrary, the texts of the Jewish mystics, including that of Zohar, reveal the presence of an all-encompassing personal Deity that addresses to the human being, as a divine central creation [4], asking him to assume a certain moral value axiom. The secret of the Name and of the decisions of this individual Deity is a theme that can be accessed only by the initiated ones, who assume the mission of saving the human being from the slippage relative to the nonobedience to the divine will. Therefore, when the Zohar suggests the appearance of uniqueness and superiority of Jews initiated over other cults of humanity, we could understand that we are not dealing with an exercise of vanity, but rather with the risky assuming of the fate of spiritual savior, willing to reveal, but also to sacrifice for all humanity.

The fusion between symbol, sign and secret in the ecstatic language used in the text of the Zohar is trying to support the possibility of the existence of a divine plan in which the human being occupies a major place, being conceptually posited within a register that includes terms such as salvation, damnation or Final Judgment [4:71]. The one who gets familiar with this language, where are reunited the sign, the symbol and the secret, would gradually acquire the ability to accede to the vision of this divine plan in which the Adamic man is judged only after passing beyond death. The theological message delivered here would represent a warning and a call to the constant reporting of human life to the divine imperatives and requests. The metaphysical description of the creation is positioned in this context, in a second plan, the ethical issues being primary, such as the propaedeutic moral individual behaviour, which prepares the consciousness to overcome the materiality and enter the transcendent paradigm, in the world of the spirit.

In the Kabbalah vision and, implicitly, in that of Zohar, the transience cannot be overcame, therefore, than by reporting to the spiritual destiny of the human being who, above all, should recognize the Creator as 
the Absolute Form and the generator Demiurgic Factor and to gain access to his Name, which brings together the totality of founding names[5]. The idea of understanding the central purpose of the human destiny as getting closer to the taumatugic position of the Divinity as a presence that gave shape to the entire universe, and that reveals itself, in a symbolic register, throughout its complexity, is a thesis proposed and debated by other representative spiritual traditions. Thus, the hermeticism recalls that the Supreme God encompasses all the possible names, being the one who gives shape and determination to the entire existence [6] and the scholastic thinking constantly evoked the image of God as an Almighty Being that lies beyond the mundane space and time, but it supports its ephemeral existence, with the divine will being fully sufficient to itself and non-relative[7]. Both in the Jewish mystical contemplation and experience and on the scholastic or hermetic levels, there is a special language that brings together the symbol, the sign and the secret. Thus, for these paradigms of spirituality that are distant in space and time, rationality is not excluded, but only situated in the extensive perimeter of the mystical experience.

\section{Conclusions}

Having regard to the considerations exposed so far, may we still talk nowadays about the presence of such expressions of mystical language that reunite the symbol, the sign and the secret? And is the usage of these three elements of meta-expression still effective? Are we still interested in the idea of nearness to the divine entity and the thesis of the teophanic union with this one [8] through contemplation and ecstatic language? The modern world can seem like a paradigm in which the man walked confidently relying on his own capacities, convinced that, since he discharged himself from the religious superstition, he will triumph, surrounded by the glory of Nietzsche's Superbuman, impetuously and expansively,[9] being subsequently confronted with the tragedies of world conflagrations and of the ideologies that have nurtured hatred of race and conflict between different social classes. The phenomenon of despiritualization and the exacerbation of materialism led not to a cancellation of the spiritual element, but on the contrary, to its withdrawal behind the curtain of the history of humanity. The symbol, the sign, and the secret, the ecstatic languages were called and used extensively within the totalitarian ideologies that have taken the form of collective idolatry. The ecstatic language that brings together the symbol, the sign and the secret was activated again and used excessively in the context of violent expressions of religious fanaticism, being often a part of the 
mechanism of motivation in the acts of radicalism in various religions of the contemporary world. This reality indicates that the human being did not often understand the function of the ecstatic language as a factor and means of closeness to the universal positiveness that implies the love for one's neighbour.

In this regard, the Zohar still is a valid benchmark nowadays as regards the way in which the religious experience and its languages can and should be used in an authentic way, that is only from and for their real purpose, namely the involvement of the human consciousness human in a spiritual ascension, where compassion occupies a central place.

\section{References}

[1] Wittgenstein L. Tractatus Logico-Philosophicus. Bucharest: Humanitas; 1991. p. 45.

[2] Furst M, Trinks J. Manual de filozofie. Bucharest: Humanitas; 1997. p.163-173.

[3] Kernbach V. Biserica în involuție. Bucharest: Politică Publishing House; 1984. p.161-162.

[4] Ben Yohai Rabbi, Rabbi Eleazar. Zoharul sau Cartea Splendorii. Bucharest: Antet Publishing House; 1997. p.47. p.71.

[5] Eliphas L. Cartea Splendorilor. Studii despre originile Kabbalei. Bucharest: Antet XX Press Publishing House; 2002. p. 66-68.

[6] Trismegistos H. Textele sacre sau În cântarea hermetică. Bucharest: Univers Enciclopedic Publishing House; 2003. p. 74-76.

[7] Boetius din Dacia. Despre eternitatea lumii. In: Despre eternitatea lumii. Bucharest: IRI Publishing House. 2007. p. 138-140.

[8] Culianu IP. Călătorii în lumea de dincolo. Bucharest: Nemira Publishing House; 1996. p. 193-194.

[9] Nietzsche F. Aşa grăit-a Zarathustra. Bucharest: Humanitas Publishing House; 1996. p. 364. 